\title{
Obituary: Daris R. Swindler (1925-2007)
}

Daris R. Swindler, Professor Emeritus of Anthropology at the University of Washington, Seattle, passed away on December 6, 2007, after a brief acute illness in Spokane. He was 82 years old. Much of his scientific work was related to dental anthropology and craniofacial growth and development. A longtime member of the Dental Anthropology Association, Swindler served as its president from 1990 to 1992. From 1996 to 2001 he belonged to the Editorial Board of Dental Anthropology. With his death dental anthropology has lost one of its finest scholars and supporters. The 14th International Symposium on Dental Morphology in Greifswald, Germany in August 2008 will commemorate his life and will honor his most valuable contribution to Dental Anthropology.

Daris R. Swindler was born in Morgantown, West Virginia in 1925. Since his junior years in highschool, Swindler had been interested in the evolution and the diversity of recent humankind. This interest was greatly fostered by the reading of "On the Trail of Ancient Man" by Roy Chapman Andrews. Interrupted by his volunteer service for the US Navy during the Second World War, Swindler began his higher education at the University of West Virginia. As a graduate student at the University of Pennsylvania he studied with Drs. Wilton H. Krogman, Loren Eisely and Carleton Coon. Especially influential was his acquaintance with Krogman that inspired his continuing interest in craniofacial growth and development, and especially of teeth.

In 1954 he participated in an expedition to New Britain with Ward Goodenough, Ann Chowning and Charles A. Valentine. This had a great impact on Daris Swindler's future work. Not only was his doctoral dissertation in Anthropology, which he completed in 1959, largely based on the material that he collected during these five months, but the time he spent with the Lakalai people assured him of his career choice as a physical anthropologist. In his most recent book "New Britain Diary, 1954: An Anthropologist's Journal", Daris R. Swindler reflects his encounter with the Lakalai [p. 34] "As I walked back along the beach that evening, all that had happened today was swimming about in my head: thoughts about our earth and its many people, its many religions and cultures, and then I realized: this is why I became an anthropologist."

Though he was never able to return to New Britain, his interest in the various cultural regions of the Pacific continued. In 1996 he joined an Italian Expedition to Easter Island as a Field Consultant in Dental

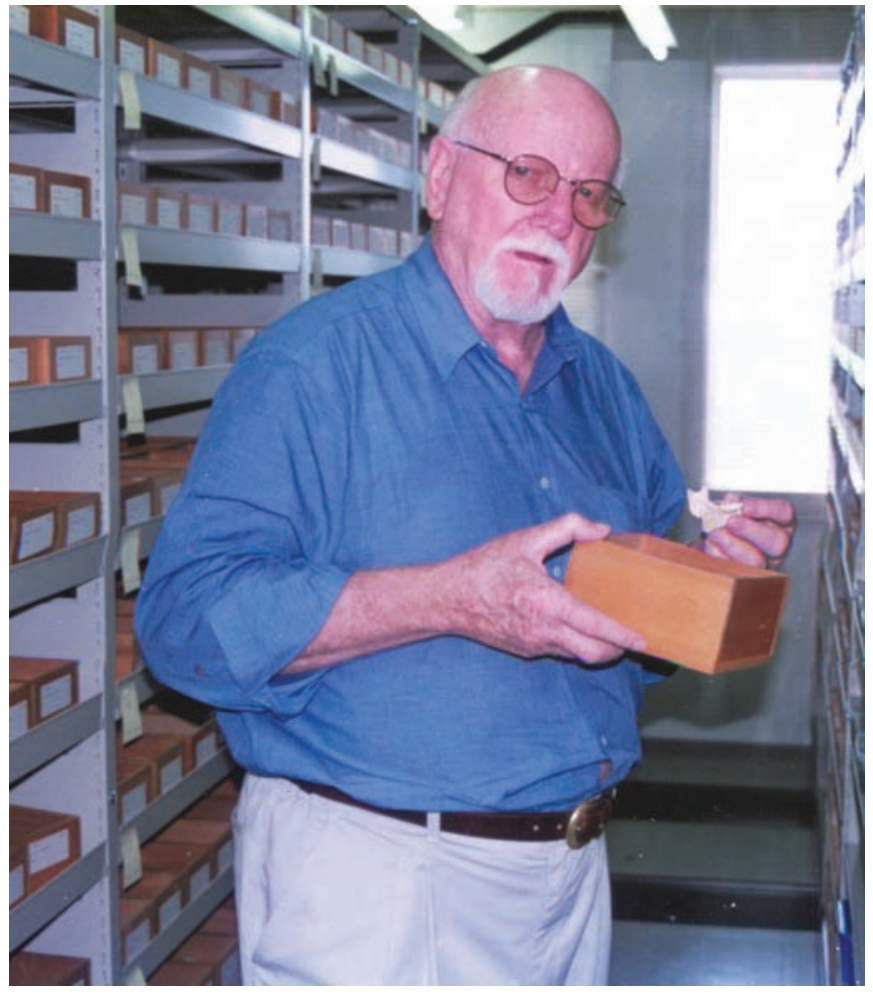

Fig. 1. Daris R. Swindler studying primate dentitions in Inuyama, Japan, in 1998.

Anthropology and one year later accepted an invitation to lecture on Micronesian Anthropology on the Oceanic Grace Cruise Line through Micronesia.

From 1954 to1968 Swindler taught human anatomy at several academic institutions including the University of Pennsylvania Graduate School of Medicine, Cornell University Medical School, West Virginia University Medical School, the Medical College of South Carolina, and Michigan State University. In 1968 Swindler was appointed full professor at the Department of Anthropology, University of Washington. Over this same time period he was also an Adjunct Curator of Primate Anatomy, Burke Memorial Washington State Museum. After his retirement in 1991 he was invited to be Visiting Professor by the University of Zurich, Switzerland (1992), the University of Padua, Italy (1994), and by the Okayama University School of Dentistry, Japan (1998).

Swindler's research interests included primate anatomy, early primate dental development, comparative dental morphology and odontometrics of living and fossil primates, as well as Pacific dental anthropology. Several field expeditions took him to important sites such as the Big Horn Basin, Wyoming 


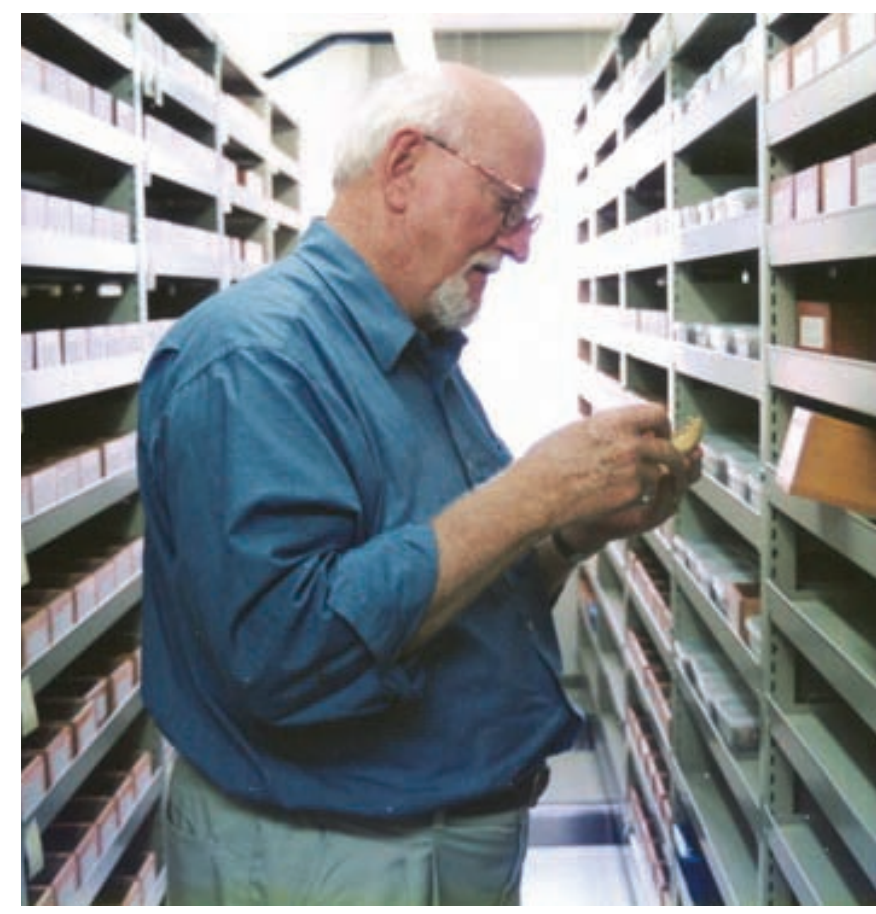

Fig. 2. Daris R. Swindler researching in Inuyama, Japan, 1998.

(1984-1990), Pakistan (1989), as well as to the Valley of the Kings, Egypt (1991). In recent years he carried out forensic work in Cyprus for Physicians for Human Rights.

His time in Seattle was very productive. Several research grants from the National Institutes of Health (NIH) allowed Swindler to conduct unique longitudinal studies on craniofacial growth and development of two primate species, the pigtailed macaque (Macaca nemestrina) and the yellow baboon (Papio cynocephalus). Huge datasets accrued from X-ray-films, dental casts, body and head measurements, which were studied extensively by Swindler and his graduate students, most notably Dr. JoyceSirianni. In addition toSwindler'sclassic work in 1973, "An Atlas of Comparative Primate Gross Anatomy, Baboon, Chimpanzee, and Man" (reprinted by Robert E. Krieger in 1982), with medical illustrator Charles D. Wood, Swindler and Sirianni published a substantial body of data in 1985 as an impressive book, "Longitudinal Growth and Development of the Pigtailed Macaque (Macaca nemestrina)" CRC Press, Boca Raton, Florida. Daris Swindler never refused scholars access to his original data. On the contrary, he often went out of his way to promote new research that made continuing use of his own data base. In 2007, shortly before his death, Daris decided to donate his enormous collection of dental casts, X-ray films, skeletons, etc. to the New York University. At the same time New York University formally established the "Daris R. Swindler Collection" of dental primate material available for study at their Center for the Study of Human Origins (http://www. nyu.edu/gsas/dept/anthro/programs/csho/center. html). This gave Daris a great sense of pride and the assurity of a productive future for his collections.

Swindler received many honors in his life, notably the Alexander Von Humboldt Senior Scientist Award from Germany; the Washington Governor's Writer's Day Award for his "An Atlas of Primate Gross Anatomy: Baboon, Chimpanzee and Man"; the Senior Award for the Visiting Scholar Exchange from the Peoples Republic of China; Vice President of the American Association of Physical Anthropologists; President of the Dental Anthropology Association. He was a member of the editorial boards of several journals including Journal of Dental Research and the Yearbook of Physical Anthropology. He was elected a Fellow of The American Association for the Advancement of Science in 1961 and in 1992 became a Fellow of The Explorer's Club.

Swindler was a gifted writer, who published constantly over more than 50 years. His first publication was in 1955 on the absence of sickle cell anemia in Melanesia. "A review of dental morphological traits in Oceania" was a chapter in a Festschrift (2005) for Ann Chowning. Apart from those already mentioned, other outstanding publications include his widely acclaimed books, "The Dentition of Living Primates" Academic Press, London, 1976; "Introduction to Primates" The University of Washington Press, Seattle and London, 1998; "Primate Dentition: An Introduction to the Teeth of Nonhuman Primates" Cambridge University Press London, 2002. Daris himself said he especially enjoyed his work as the major editor of "Systematics, Evolution and Anatomy", Vol. 1 of Comparative Primate Biology, Alan R. Liss Publishing Company, 1986 (with J. Erwin as Series Editor).

Apart from his outstanding contribution to dental

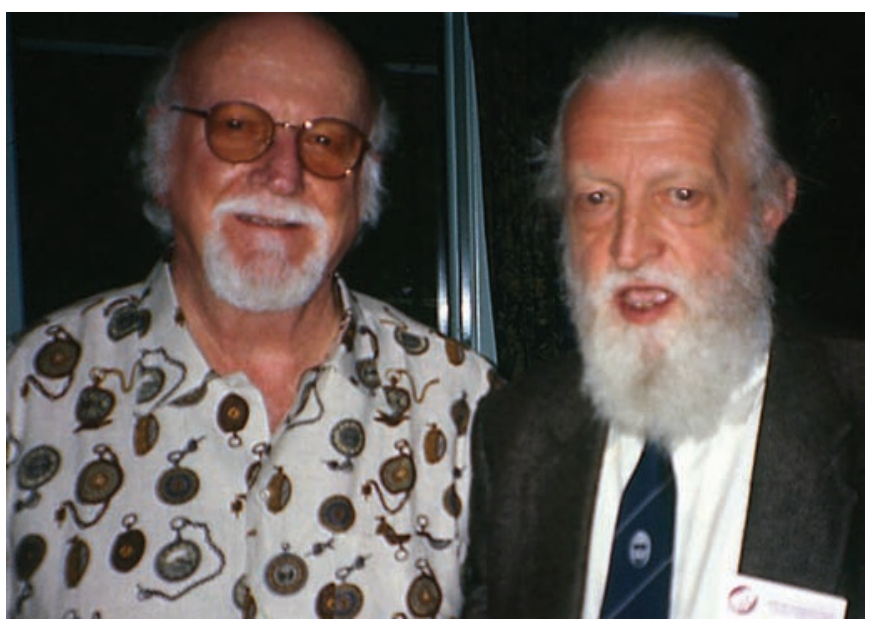

Fig. 3. Daris R. Swindler (left) and C. Loring Brace, both past-presidents of the Dental Anthropology Association. Picture taken at the AAPA meeting, 1996 (courtesy of E. F. Harris). 


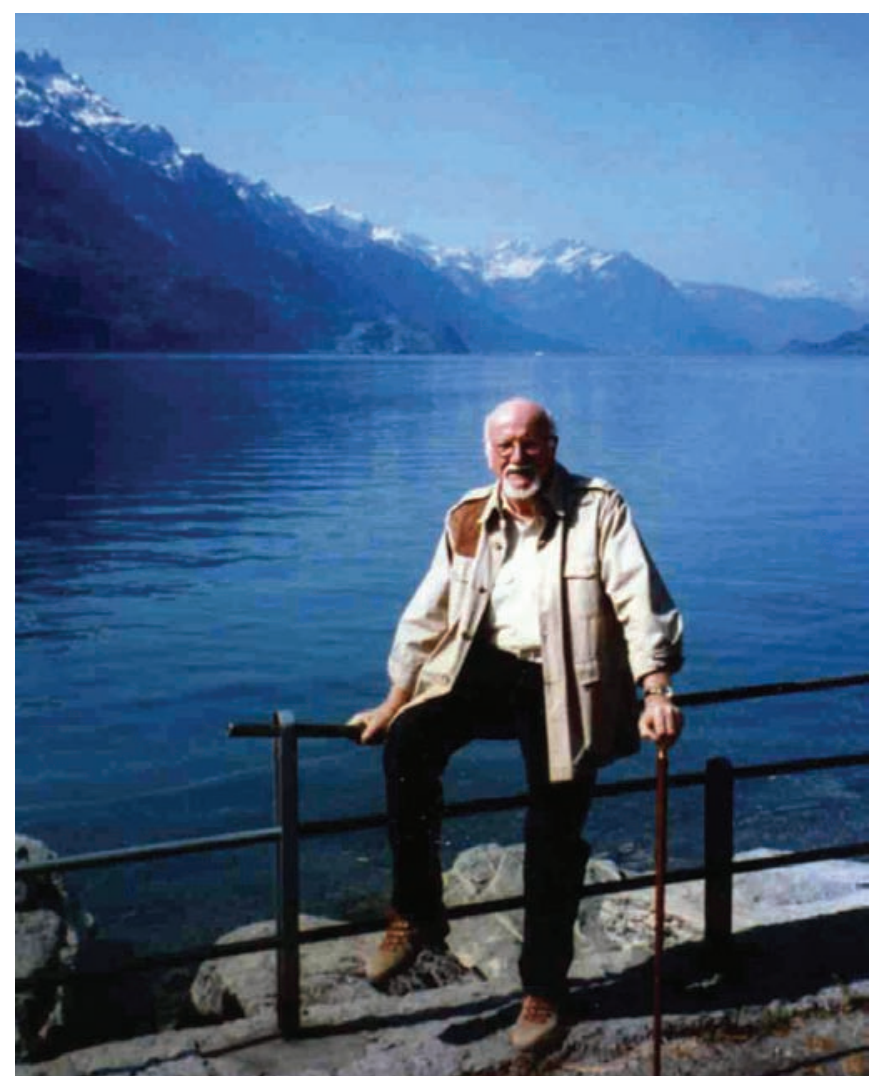

Fig. 4. Daris R. Swindler in Switzerland.

morphology and primate anatomy, Swindler was known for his passion for teaching. His courses on Comparative Primate Anatomy were particularly popular with his students. Shortly before his death, Daris was honored by the establishment of the Daris R. Swindler Fellowship in Biocultural Anthropology in the Department of Anthropology of the University of Washington. This fellowship marks a lasting contribution to Anthropology in his name and will provide a great opportunity for many future students at the University of Washington.

As a truly biological anthropologist, Daris R. Swindler enjoyed life and its many facets to the fullest. He was always fascinated about all aspects of evolutionary biology, and loved to chat about his many interests, most notably about primate teeth. From all of the many meetings he attended, he especially favored the International Symposia on Dental Morphology because of their special flavor and small size which encourages scientific discussions about so many aspects of dental morphology both in primates and other vertebrates. He was especially passionate about key historical figures, none more so than Charles Darwin and was never prouder than when he could extend his private library with another book on the subject. He and his wife Kathy Swindler were great hosts not just for well-known and established academics, but also for many young researchers who were still at the start of their careers. Many felt, and still feel, part of Daris and Kathy's extended scientific family and many, through their friendship and support, were inspired to keep going. Daris had an overwhelming trust in the future and his friends felt his love for his academic family. Apart from science he loved fishing in the Puget Sound and was almost fanatical about American Football.

Daris R. Swindler is survived by his wife Kathryn Rantala Swindler of Spokane, seven children and seven grandchildren. Everyone who knew him will agree that Daris was a wonderful person. He will deeply be missed by all those to have shared so much with him and have learned so much from him though he will remain a part of dental anthropology for a very long time to come.

Christopher Dean
University College London
United Kingdom
and
Thomas Koppe
Ernst Moritz Arndt University
Greifswald
Germany

\section{Bibliography, Daris R. Swindler}

Swindler DR. 2007. New Britain diary, 1954: an anthropologist's journal. Spokane: Ravenna Press.

Koppe T, Swindler DR. 2004. Metric sexual dimorphism in the deciduous teeth of Old World monkeys. Ann Anat 186:367-374.

Willis MS, Swindler DR. 2004. Molar size and shape variations among Asian colobines. Am J Phys Anthropol 125:51-60.

Swindler DR. 2002. Primate dentition: an introduction to the teeth of non-human primates. (CambridgeStudies in Biological and Evolutionary Anthropology.) Cambridge: Cambridge University Press.

Swindler DR. Fourth molars in the Anthropoidea. Dental Anthropology 2002;16:26-28.

Swindler DR, Drusini AG, Cristino C, Ranzato R. 1999. Comparison of molar crown size of precontact Easter Islanders and others. In: Mayhall JT, Heikkinen T, editors. Dental morphology 1998. Oulu: Oulu University Press, p 63-73.

Koppe T, Swindler DR, Lee SH. 1999. A longitudinal study of the growth pattern of the maxillary sinus in the pig-tailed macaque (Macaca nemestrina). Folia Primatol (Basel) 70:301-312. 
Koppe T, Rae TC, Swindler DR. 1999. Influence of craniofacial morphology on primate paranasal pneumatization. Ann Anat 181:77-80.

Siebert JR, Williams B, Collins D, Winkler LA, Swindler DR. 1998. Spontaneous cleft palate in a newborn gorilla (Gorilla gorilla gorilla). Cleft Palate Craniofac J 35:436-441.

Winkler LA, Schwartz JH, Swindler DR. 1996. Development of the orangutan permanent dentition: assessing patterns and variation in tooth development. Am J Phys Anthropol 99:205-220.

German RZ, Hertweck DW, Sirianni JE, Swindler DR. 1994. Heterochrony and sexual dimorphism in the pigtailed macaque (Macaca nemestrina). Am J Phys Anthropol 93:373-380.

Lestrel PE, Bodt A, Swindler DR. 1993. Longitudinal study of cranial base shape changes in Macaca nemestrina. Am J Phys Anthropol 91:117-129.

Emel LM, Swindler DR. 1992. Underbite and the scaling of facial dimensions in colobine monkeys. Folia Primatol (Basel) 58:177-189.

Swindler DR, Emel LM. 1990. Dental development, skeletal maturation and body weight at birth in pigtail macaques (Macaca nemestrina). Arch Oral Biol 35:289-294.

Kirch PV, Swindler DR, Turner CG 2nd. 1989. Human skeletal and dental remains from Lapita sites (1600500 B.C.) in the Mussau Islands, Melanesia. Am J Phys Anthropol 79:63-76.

Haglund WD, Reay DT, Swindler DR. 1989. Canid scavenging/disarticulation sequence of human remains in the Pacific Northwest. J Forensic Sci 34:587-606.

Haglund WD, Reay DT, Swindler DR. 1988. Tooth mark artifacts and survival of bones in animal scavenged human skeletons. J Forensic Sci 33:985-997.

Swindler DR, Olshan AF. 1988. Comparative and evolutionary aspects of the permanent dentition. In: Schwartz JH, editor. Orang-utan biology. New York: Oxford University Press, p 271-282.

Swindler DR, Ward S. 1988. Evolutionary and morphological significance of the deflecting wrinkle in the lower molars of the Hominoidea. Am J Phys Anthropol 75:405-411.

Swindler DR, editor. 1986. Systematics, evolution and anatomy. New York: Alan R. Liss.

Sirianni JE, Swindler DR. 1985. Growth and development of the pigtailed macaque. Boca Raton: CRC Press, Inc.

Olshan AF, Siegel AF, Swindler DR. 1982. Robust and least-squares orthogonal mapping: methods for the study of cephalofacial form and growth. Am J Phys Anthropol 59:131-137.

Swindler DR, Olshan AF, Sirianni JE. 1982. Sex differences in permanent mandibular tooth development in Macaca nemestrina. Hum Biol 54:45-52.
Sirianni JE, Van Ness AL, Swindler DR. 1982. Growth of the mandible in adolescent pigtailed macaques (Macaca nemestrina). Hum Biol 54:31-44.

Swindler DR, Olshan AF. 1982. Molar size sequence in Old World monkeys. Folia Primatol (Basel) 39:201212.

Daniel HJ, Schmidt RT, Olshan AF, Swindler DR. 1982. Ontogenetic changes in the bony labyrinth of Macaca mulatta. Folia Primatol (Basel) 38:122-129.

Swindler DR. 1979. The incidence of underbite occlusion in leaf-eating monkeys. Ossa 6:261-272.

Swindler DR. 1978. The teeth of primates. Burlington, NC: Carolina Biological Supply Company.

Turner CG 2nd, Swindler DR. 1978. The dentition of New Britain West Nakanai Melanesians. VIII. Peopling of the Pacific. Am J Phys Anthropol 49:361-371.

Swindler DR. 1976. Dentition of living primates. New York: Academic Press.

Garn SM, Swindler DR, Minnis PE. 1975. The sex difference in dimensional communalities in Macaca nemestrina. Am J Phys Anthropol 43:19-22.

Swindler DR, Sirianni JE. 1975. Tooth and body size correlations in Macaca nemestrina. J Dent Res 54:695.

Sirianni JE, Swindler DR. 1975. Size variability within the deciduous dentitions of male and female Macaca nemestrina. J Dent Res 54:414.

Sirianni JE, Swindler DR, Tarrant LH. 1975. Somatometry of newborn Macaca nemestrina. Folia Primatol (Basel) 24:16-23.

Orlosky FJ, Swindler DR, McCoy-Beck HA. 1974. Metric trends of the anterior teeth in African monkeys. Hum Biol 46:647-661.

Chase CE, Swindler DR. 1974. A system for automatic recording of odontometric material. J Dent Res 53:1506.

Swindler DR, Wood DC. 1973. An atlas of primate gross anatomy: baboon, chimpanzee, and man. Seattle: University of Washington Press.

Tarrant LH, Swindler DR. 1973. Prenatal dental development in the black howler monkey (Alouatta caraya). Am J Phys Anthropol 38:255-259.

Sirianni JE, Swindler DR. 1973. Inheritance of deciduous tooth size in Macaca nemestrina. J Dent Res 52:179.

Swindler DR, Sirianni JE. 1973. Palatal growth rates in Macaca nemestrina and Papio cynocephalus. Am J Phys Anthropol 38:83-91.

Swindler DR, Tarrant LH. 1973. The topography of the premaxillary-frontal region in nonhuman primates. Folia Primatol (Basel) 19:18-23.

Swindler DR, Orlosky FJ.1972. Metric and morphological variability in the dentition of colobine monkeys. J Hum Evol 3:135-160.

Tarrant LH,Swindler DR. 1972. The state of the deciduous dentition of a chimpanzee fetus (Pan troglodytes). J Dent Res 51:677.

Swindler DR, Merrill OM. 1971. Spontaneous cleft lip 
and palate in a living nonhuman primate, Macaca mulatta. Am J Phys Anthropol 34:435-439.

Swindler DR, Sirriani JE. 1969. Variability of maxillary incisors among primates. VIIIth Int Congr Anthrop Ethnol Sci, S-2 Dental Aspects, p 308-311.

Aulerich RJ, Swindler DR. 1968. The dentition of the mink (Mustela vison). J Mammal 49:488-494.

Swindler DR. 1968. The maxillary incisors and evolution of Old World monkeys. In: Chiarelli B, editor. Taxonomy and phylogeny of Old World primates with references to the origin of man. Torino, Italy: Rosenberg and Sellier, p 57-67.

Swindler DR, Orlosky FJ, Hendrick AG. 1968. Calcification of the deciduous molars in baboons (Papio anubis) and other primates. J Dent Res 47:167170.

Swindler DR, McCoy JA, Hornbeck PV. 1967. The dentition of the baboon (Papio anubis). In: Vagtborg $\mathrm{H}$, editor. The baboon in medical research, Vol. II. Austin: University of Texas Press, p 133-150.

Garn SM, Lewis AB, Swindler DR, Kerewsky RS. 1967. Genetic control of sexual dimorphism in tooth size. J Dent Res 46:963-972.

Hornbeck PV, Swindler DR. 1967. Morphology of the lower fourth premolar of certain cercopithecidae. J Dent Res 46:979-983.

Swindler DR. 1967. Lawrence Oschinsky: 1921-1965. Am J Phys Anthropol 26:371-372.

Swindler DR, Gavan JA. 1966. Variability of mandibular tooth formation in the rhesus monkey. J Dent Res 45:1234.

Gavan JA, Swindler DR. 1966. Growth rates and phylogeny in primates. Am J Phys Anthropol 24:181190.

Swindler DR, McCoy HA. 1965. Primate odontogenesis. J Dent Res 44:suppl:283-295.

SwindlerDR, McCoyHA.1964. Calcification of deciduous teeth in Rhesus monkeys. Science 144:1243-1244.

Swindler DR, Gavan JA, Turner WM. 1963. Molar tooth size variability in African monkeys. Hum Biol 35:104122.

Mavawala J, Swindler DR, Hunt EE Jr. 1963. The dermatoglyphics of the West Nakanai of New Britain. Am J Phys Anthropol 21:335-340.

Swindler DR, Gavan JA. 1962. Calcification of the mandibular molars in rhesus monkeys. Arch Oral Biol 7:727-734.

Swindler DR. 1961. Calcification of the permanent first mandibular molar in rhesus monkeys. Science 134:566.

Graydon JJ, Semple NM, Simmons RT, Swindler DR. 1956. A blood group genetical survey in West Nakanai, New Britain. Am J Phys Anthropol 14:275286.
Swindler DR. 1955. The absence of the sickle cell gene in several Melanesian societies and its anthropologic significance. Hum Biol 27:284-293.

[An electronic version of this bibliography is available on request. Editor]

\section{The Daris Swindler Primate Dental Cast Collection}

In August 2006 Daris agreed to donate his collection of primate dental casts to the Center for Human Origins, New York University. The collection consists of more than 2,000 casts representing every primate species known (and some non-primate relatives), as well as several human populations. The Daris Swindler Primate Dental Cast Collection is now housed in the Anthropology Department of NYU. Undergraduate volunteers are in the process of inventorying the collection and comparing it against Daris' catalog. Inventory is expected to be complete by December of 2008. The collection has already been used for a number of undergraduate and graduate student projects. In addition, researchers who are members of the New York Consortium for Evolutionary Primatology have begun scanning some of the ape casts for comparative study. Ultimately, NYU plans to scan the entire collection in three-dimensions and make it virtually available for remote researchers via an internet database. The collections will provide the foundation for developing standards for scoring non-human primate dental morphological variation. Many important studies of human and non-human primate variation as well as growth and development are in the works. NYU now anticipates working with Kathy Swindler to arrange the transfer of the remaining collection, which includes measurements and radiographs from an 8-year growth study of Macaca nemestrina, several hundred tooth buds from several species of nonhuman primates, and additional human collections from New Guinea Highlands and New Britian. NYU and Dr. Bailey, in particular, are greatly indebted to Daris for this generous donation.

Shara Bailey

New York University

E-mail: sbailey@nyu.edu 